\title{
The Relationship Between the Tax Burden and Financing Public Services: A Comparison of Ukraine and European Countries
}

\author{
Iaryna Samusevych
}

$\mathrm{PhD}$, Assistant of the Department of Accounting and Taxation, Sumy State University, Ukraine

\begin{abstract}
Ali Shamaelh
Head of Revenue Department, Financial Affairs Administration, Ministry of Foreign Affairs and Expatriates, Amman, Jordan
\end{abstract}

\begin{abstract}
The strategy of reforming the country's tax system should consider the real effect that taxpayers receive in response to their tax payments, that is, the level of financing public services. The article formalizes the links between the tax burden and financing public services since multifactor dependencies using the panel regression method with fixed effects for Ukraine and 10 countries - its tax competitors (Bulgaria, Georgia, Latvia, Lithuania, Romania, the Czech Republic, Estonia, Slovakia, Moldova, Serbia).

Based on the calculations, it was found that the existing level of tax burden in Ukraine is overstated, while the optimal level in 2012 was: 1) the total tax burden - 14.39-18.09\% of GDP; 2 ) the burden on legal entities $45.99-48.32 \%$ of the profits of enterprises; 3 ) the burden on individuals $-11.92-28.75 \%$ of wages. These values correspond to the actual amounts of government spendings on financing public services.
\end{abstract}

Keywords: tax burden, optimal level, financing, public services, competitiveness, tax competition.

JEL Classification: H20.

(C) The Authors, 2017. This article is published with open access at ARMG Publishing.

\section{Introduction}

There is a significant convergence of taxation conditions, leading to a decrease in the influence of directly quantitative taxation conditions on the decision-making on the placement of taxation objects and shifting emphasis on accounting for non-tax factors, characterizing the overall level of the country's development at he present stage of the development of international tax competition between countries. This trend is confirmed by the results of a survey conducted by consulting company KPMG in the UK in 2014 where 104 respondents participated and only $18 \%$ of them noted the high influence of the taxation regime on the company's choice of production location, which is $5 \%$ less than in 2009 ; for $48 \%$ of companies the taxation regime has a certain influence on the choice of the country for conducting business (in 2009 this indicator was $56 \%$ ); while $33 \%$ of respondents did not attach importance to taxation conditions when choosing a country for production activities, which is 12\% higher than the same indicator as of 2009 (KPMG Annual Survey of Tax Competitiveness 2014).

That is why it is advisable to develop a strategy to increase the country's tax competitiveness, not only in the direction of increasing the attractiveness of taxation conditions for taxpayers, mainly due to a reduction in the level of tax burden on mobile factors of production, but also taking into account the macroeconomic conditions of development in the country. In this context, the level of public services provision in countries - tax rivals acquires paramount importance, which rational taxpayers correlate with the general level of taxation in order to compare the effect received in response to tax payments made by them and form their final decision when choosing jurisdiction for the placement of taxable objects.

The aim of the work is to formalize the link between the financing public services by the tax burden, as well as to determine the optimal levels of tax burden in the conditions of tax competition in Ukraine and countries who are its tax competitors given the actual level of financing public services.

\section{Literature review}

Theoretical bases and practical tools for the tax system formation in the context of tax competition have been studied in the scientific works of such foreign scientists as J. Wilson, A.M. Libman, D. Mitchell, W. Oates, 
T. Field. It should be noted that the connection between the tax burden and the level of public services that the country provides to taxpayers was investigated by $\mathrm{C}$. Tiebout in the middle of the 20th century with the identification of direct dependence, it is quite natural, given the fact that the main source of public expenditure for financing public services is income from tax. At the same time, it ought to be remarked that in jurisdictions with a similar level of taxation, the volume and quality of public services provision may differ significantly, which is due to the influence of subjective factors, such as the level of irrational spending of state financial resources by the government, as confirmed by the study of D. Wilson and R. Gordon or the effectiveness of fiscal policy, as reflected in the work of D. Wildasin.

\section{Methods and results}

The following methods of scientific knowledge were used in the work: analysis, synthesis, logical generalization as well as economic and mathematical modeling using the panel regression method with fixed effects, conducted by means of software product STATA 12.0.

Three tax load indicators were selected for the study for which an optimal (state-guaranteed level) level will be assessed in the context of tax competition: 1) Total tax burden $\left(\operatorname{Tax}_{G D P}\right)$ - an indicator reflecting the level of tax revenue as a percentage of the country's GDP; 2) tax burden on legal entities (Tax Profit - an indicator reflecting the level of taxes and mandatory payments (with the exception of indirect taxes and taxes paid by enterprises as tax agents for example personal income tax) as a percentage of profits; 3) tax burden on individuals $\left(\operatorname{Tax}_{\text {Salary }}\right)$ - an indicator that characterizes the level of income tax on income and social contributions as a percentage of gross wages.

To determine the impact of the level financing public services in the country's economy on the level of the optimal tax burden, an array of factor characteristics was formed, the characteristics of which are presented in Table 1.

Table 1. Indicators of the level of financing public services

\begin{tabular}{|l|l|}
\hline $\begin{array}{c}\text { Indicator } \\
\text { designation }\end{array}$ & \multicolumn{1}{c|}{ Characteristic of the indicator } \\
\hline$E E_{G D P}$ & Public expenditure on education, as \% of GDP \\
\hline$H E_{G D P}$ & Public expenditure on health as \% of GDP \\
\hline$S E_{G D P}$ & Public expenditure on social protection, as \% of GDP \\
\hline$T C E_{G D P}$ & Public expenditure on transport and communications, as \% of GDP \\
\hline$D E_{G D P}$ & State defense spending, as \% of GDP \\
\hline$A E_{G D P}$ & Public expenditure on agriculture, as \% of GDP \\
\hline$M E_{G D P}$ & Government spending on financing the extractive industry, as \% of GDP \\
\hline$T E_{G D P}$ & Total public expenditure on public services, as \% of GDP \\
\hline$E E_{p c}$ & $\begin{array}{l}\text { Public expenditure on education, in terms of monetary units at purchasing power parity, as compared to data of 2005, } \\
\text { per capita }\end{array}$ \\
\hline$H E_{p c}$ & Public expenditure on health, in monetary terms at purchasing power parity to the levels of 2005 per capita \\
\hline$S E_{p c}$ & $\begin{array}{l}\text { Public expenditure on social protection, in monetary units at purchasing power parity up to the level of } 2005 \text { per } \\
\text { capita }\end{array}$ \\
\hline$T C E_{p c}$ & $\begin{array}{l}\text { Public expenditure on transport and communications, in monetary units at purchasing power parity up to the level of } \\
\text { 2005 per capita }\end{array}$ \\
\hline$D E_{p c}$ & State defense spending, in terms of monetary units at purchasing power parity up to the level of 2005 per capita \\
\hline$T E_{p c}$ & $\begin{array}{l}\text { Total government expenditure for financing public services, in monetary units at purchasing power parity up to the } \\
\text { level of } 2005 \text { per capita }\end{array}$ \\
\hline
\end{tabular}

Two groups of parameters for financing public services were used in the calculation process: indicators reflecting the share of government spendings on providing the appropriate type of public goods in the country's GDP, as well as the amount of public financing of a certain type of public services in monetary terms per capita. The study was conducted for Ukraine and 10 countries - its main tax competitors (Bulgaria, Georgia, Latvia, Lithuania, Romania, the Czech Republic, Estonia, Slovakia, Moldova, Serbia) by constructing multifactor dependencies using the panel regression method with fixed effects, which, on the one hand, allows to determine the overall effect of factorial signs on the resultant for all objects of research, and on the other hand, ensures that the specific features of the countries under evaluation are taken into account. To separate the role of the level of financing public services from the rest of macroeconomic conditions for 
the development of countries, the control variables were used: 1) GDP growth rate $\left(\mathrm{GDP}_{g r}\right)$ - in models where the factor factors are parameters reflecting the share of government spending on public service financing in the country's GDP; 2) GDP per capita $\left(G D P_{p c}\right)$ - in models with factorial signs characterizing the volume of a certain type of public expenditure per capita.

The sources of statistical information for conducting practical calculations are the World Bank database, the statistical database Collecting Taxes USAID, statistical information of the International Food Policy Research Institute. The study period, when formalizing the connection between the level of financing public services and the level of the tax burden, covers 1992-2012 for the aggregate tax burden; 2005-2012 - for tax burden on legal entities; 2007-2012 - for the tax burden on individuals, due to the limited availability of statistical data for all countries in open access. To define the optimal level of aggregate tax burden, which is justified by the volume of public expenditure in the context of tax-rival countries, 14 models were constructed illustrating the relationship between individual indicators of public expenditure and the level of the tax burden in general for the countries assessed, the parameters of which are presented in Table 2.

Table 2. Yvaluation findings of the relationship between the level of financing public services and the level of aggregate tax burden

\begin{tabular}{|c|c|c|c|c|c|}
\hline \multirow[b]{2}{*}{$\begin{array}{l}\text { Public expenditure } \\
\text { parameter }\end{array}$} & \multicolumn{2}{|c|}{ Coefficient in the regression equation } & \multirow[b]{2}{*}{ Fact. } & \multirow[b]{2}{*}{$F_{\text {crit. }}$} & \multirow[b]{2}{*}{ Prob $>$ F } \\
\hline & $\begin{array}{l}\text { at a parameter of the } \\
\text { state expenses }\end{array}$ & $\begin{array}{l}\text { at the control } \\
\text { variable }\end{array}$ & & & \\
\hline$E E_{G D P}$ & $\begin{array}{c}1.199 * * * \\
(4.19)\end{array}$ & $\begin{array}{l}0.042 \\
(0.94)\end{array}$ & 8.79 & 3.06 & 0.0003 \\
\hline$H E_{G D P}$ & $\begin{array}{l}1.910 * * * \\
(3.64)\end{array}$ & $\begin{array}{l}0.058 \\
(1.20)\end{array}$ & 6.64 & 3.06 & 0.0018 \\
\hline$S E_{G D P}$ & $\begin{array}{c}1.299 * * * \\
(8.00)\end{array}$ & $\begin{array}{c}0.106^{* *} \\
(2.52)\end{array}$ & 32.05 & 3.06 & 0.0000 \\
\hline$T C E_{G D P}$ & $\begin{array}{l}1.760 * * * \\
(5.54)\end{array}$ & $\begin{array}{l}0.018 \\
(0.40)\end{array}$ & 15.33 & 3.06 & 0.0000 \\
\hline$D E_{G D P}$ & $\begin{array}{c}1.794 * * * \\
(10.63)\end{array}$ & $\begin{array}{l}-0.009 \\
(-0.25)\end{array}$ & 56.50 & 3.06 & 0.0000 \\
\hline$A E_{G D P}$ & $\begin{array}{l}2.222 * * * \\
(3.15)\end{array}$ & $\begin{array}{l}0.017 \\
(0.37)\end{array}$ & 4.95 & 3.06 & 0.0084 \\
\hline$M E_{G D P}$ & $\begin{array}{l}-4.203^{*} \\
(-1.96)\end{array}$ & $\begin{array}{l}0.027 \\
(0.83)\end{array}$ & 3.17 & 3.06 & 0.1190 \\
\hline$T E_{G D P}$ & $\begin{array}{c}0.462 * * * \\
(13.23)\end{array}$ & $\begin{array}{c}0.166^{* * *} \\
(4.93)\end{array}$ & 87.52 & 3.06 & 0.0000 \\
\hline$E E_{p c}$ & $\begin{array}{l}0.000 \\
(0.03)\end{array}$ & $\begin{array}{l}0.000 \\
(0.72)\end{array}$ & 0.34 & 3.06 & 0.7153 \\
\hline$H E_{p c}$ & $\begin{array}{l}-0.004 \\
(-1.41) \\
\end{array}$ & $\begin{array}{l}0.000 \\
(1.61)\end{array}$ & 1.33 & 3.06 & 0.2673 \\
\hline$S E_{p c}$ & $\begin{array}{l}0.001 \\
(1.15)\end{array}$ & $\begin{array}{l}-0.000 \\
(-0.09)\end{array}$ & 1.00 & 3.06 & 0.3727 \\
\hline$T C E_{p c}$ & $\begin{array}{l}0.003 \\
(0.82)\end{array}$ & $\begin{array}{l}-0.000 \\
(-0.14)\end{array}$ & 0.67 & 3.06 & 0.5115 \\
\hline$D E_{p c}$ & $\begin{array}{c}0.030 * * * \\
(8.47)\end{array}$ & $\begin{array}{l}-0.000 \\
(-2.99)\end{array}$ & 36.41 & 3.06 & 0.0000 \\
\hline$T E_{p c}$ & $\begin{array}{l}0.001 * * \\
(2.54)\end{array}$ & $\begin{array}{l}-0.000 \\
(-1.34)\end{array}$ & 3.85 & 3.06 & 0.0237 \\
\hline
\end{tabular}

Note: the values of t-statistics are presented in parentheses, *** the significance of communication at the level of $99 \%$, the significance of communication at the level of $90 \%$

It should be noted that according to the Fisher criterion, 10 out of 14 constructed models were adequate, according to which the formalization of the links between the level of the aggregate tax burden and the level of financing public services can be represented as follows (equation 1).

$$
\begin{aligned}
& \operatorname{Tax}_{G D P}=0.462 T E_{G D P}+0.166 G D P_{g r}+1.355 \\
& \operatorname{Tax}_{G D P}=1.910 H E_{G D P}+0.058 G D P_{g r}+7.428
\end{aligned}
$$




$$
\begin{aligned}
& \operatorname{Tax}_{G D P}=1.199 E E_{G D P}+0.042 G D P_{g r}+10.093 \\
& \operatorname{Tax}_{G D P}=1.299 S E_{G D P}+0.106 G D P_{g r}+8.635 \\
& \operatorname{Tax}_{G D P}=1.760 T C E_{G D P}+0.018 G D P_{g r}+12.268 \\
& \operatorname{Tax}_{G D P}=1,794 D E_{G D P}-0.009 G D P_{g r}+12.632 \\
& \operatorname{Tax}_{G D P}=2.222 A E_{G D P}+0.017 G D P_{g r}+13.441 \\
& \operatorname{Tax}_{G D P}=-4.203 M E_{G D P}+0.027 G D P_{g r}+16.067 \\
& \operatorname{Tax}_{G D P}=0.001 T E_{p c}-0.000 G D P_{p c}+14.591 \\
& \operatorname{Tax}_{G D P}=0.030 D E_{p c}-0.000 G D P_{p c}+13.394
\end{aligned}
$$

Figure 1 shows the ratio of the actual and estimated level of aggregate tax burden in Ukraine, which corresponds to the level of total public expenditure in GDP. Analyzing the data of Figure, we note that during the period, the actual indicator mostly exceeds the calculated one, which indicates a permanent underfunding of public services.

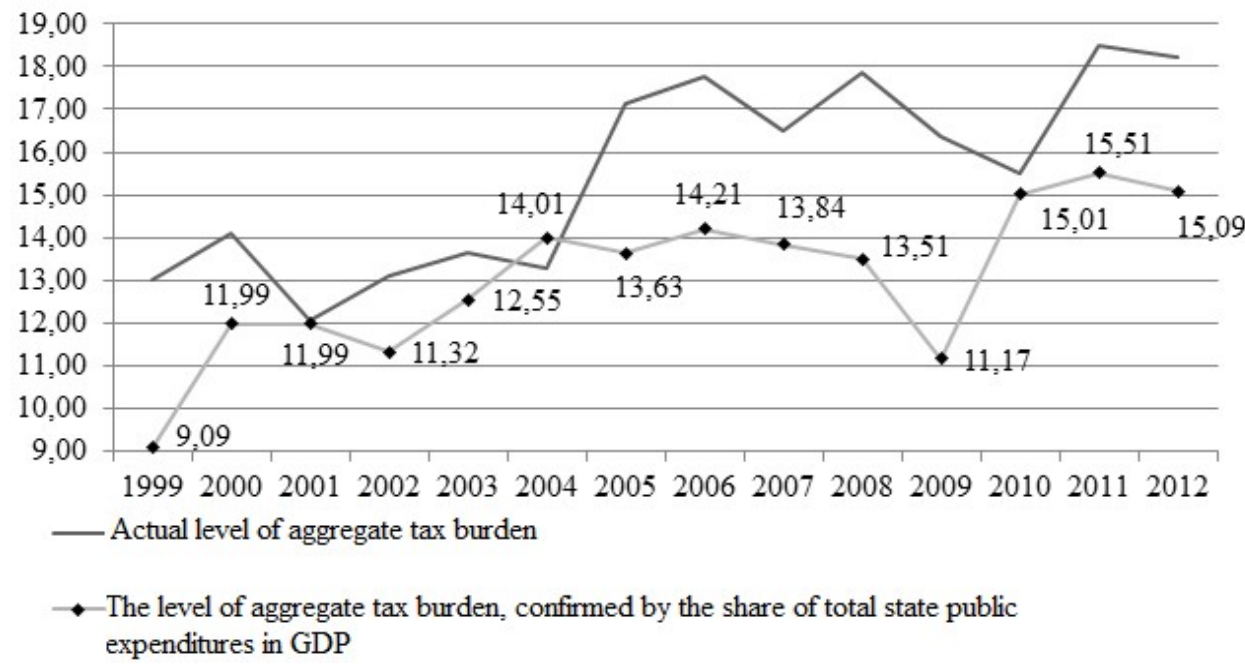

Figure 1. Correspondence of the actual level of the aggregate tax burden to the tax burden, justified by the real total public expenditure in Ukraine in 1999-2012

At the same time, the results of calculations of similar indicators for the countries - the main tax competitors of Ukraine, show that underfinancing of public services during the analyzed period is also observed in Bulgaria, Georgia, Slovakia and Serbia, while Estonia, Latvia, the Czech Republic, Romania, Lithuania and Moldova at the end of the study period provide aggregate public expenditure at a higher level than the aggregate tax burden recorded in countries, which gives them an additional advantage in terms of tax competition.

In the context of this study, it is also of interest to compare the actual level of aggregate tax burden and its significance, confirmed by the level of public expenditure in certain areas of financing public services, which helps to identify the most problematic positions in the realization of the socio-economic functions of the state (Table 3 in Appendix).

So, in Ukraine it is possible to note the discrepancy between the level of financing health care and the volume of actual tax payments in 2000, 2005-2009 and 2011-2012, while in 2001-2004 and in 2010 the financing in this direction can even be considered excessive. Separately, we should note the indicators obtained for 1999, which show the maximum balance of state fiscal and expenditure policies.

Regarding the situation in Ukraine's tax competition countries, we note that, in comparison with the actual tax burden, the most qualitative financial provision for health care is fixed for the Czech Republic, Slovakia, 
Estonia, Latvia, Lithuania, while Bulgaria, Moldova, Serbia, Romania, Georgia are characterized by underfinancing of this sphere.

It should be noted that for quite a long period of time in Ukraine there has been considerable funding for education in the context of public spending, which provided additional benefits in the context of tax competition. At the same time, it should be noted that as of 2012 the level of financing public expenditure to the maximum extent corresponded to the established level of aggregate tax burden.

One can not make an unambiguous conclusion about the costs of social protection from the point of view of their role in the formation of Ukraine's tax competitiveness, since for some of the periods studied there is underfunding of this direction, and in other years there is a "reserve" for increasing the level of the tax burden.

The results of calculations for the rest of the countries show that in the Czech Republic, Estonia, Serbia, the estimated level of the tax burden due to social security expenditure exceeds its actual level, which indicates that these countries have obtained competitive advantages, while the indicators obtained for Bulgaria, Latvia, Lithuania, Moldova, Slovakia, Georgia, Romania characterize the underfunding of this area of public services relative to the actual level of tax burden in the most of analyzed periods.

An important role in the conditions of tax competition from the point of view of ensuring geopolitical and, therefore, economic stability is the level of defense spending in the country. Starting from 2005, in Ukraine, there was an imbalance in the level of the tax burden and this group of government expenditure, which led to underfunding of this direction in comparison with the actual level of tax burden and, accordingly, the loss of additional advantages in terms of forming the tax competitiveness of the national economy, since the actual level of tax burden was significantly overestimated.

Given the level of defense expenditure of the government, one can note the overstatement of aggregate tax burden in countries such as Serbia, Moldova, Romania, Bulgaria, while Slovakia, Estonia, Georgia, Lithuania, Latvia, and the Czech Republic have demonstrated the best competitive positions in this context during the study period.

An important group of parameters for the realization of social and economic functions of the country is the volume of aggregate social expenditure per capita which serves as a criterion for the well-being of the territory. It should be noted that the results of calculations indicate a significant variation in the ratio of this indicator to the level of tax burden in Ukraine, so, during 1999-2004, the level of public spending per capita was quite significant in the domestic economy, which made it possible to increase the tax burden and the competitiveness of the national tax system in the European tax area. However, in subsequent periods, it should be noted that the given direction is underfunded compared to the level of collected tax revenues, which indicates an overestimation of aggregate tax burden. It is also worth paying attention to the results obtained for 2010, in which the actual level of aggregate tax burden can be considered optimal, given the real volume of public expenditure per capita.

In the context of countries that are tax competitors, the results of the calculations show that the tax burden is overestimated compared to the real total public expenditure per capita in Bulgaria, Romania, Georgia, Moldova and Serbia, as well as the availability of additional opportunities to increase it, justified by the actual level of this parameter in the Czech Republic, Latvia, Lithuania, Estonia, Slovakia.

Summarizing the results obtained (see Table 3), we can conclude that the optimal level is the tax burden that is within the range defined by the minimum and maximum calculated level of the indicator, which corresponds to the real level of public expenditure.

Consequently, during the study period, the level of aggregate tax burden optimal from the point of view of ensuring the state's tax competitiveness was fixed in 1999-2003 and 2005-2010. Note that in 2004 there were reasonable opportunities to increase the level of the indicator without losing tax competitive positions. Next to this, according to the results of 2011-2012, we can state an overestimation of the level of aggregate tax burden, which does not correspond to the real level of realization of social and economic functions of the state and indicates a decrease in the level of Ukraine's tax competitiveness.

In the context of this study, calculations should also be conducted to determine the optimal tax burden on legal entities and individuals, since it is the tax burden on these tax groups that has the greatest impact on the results of tax competition for participating countries (Table 4). 
Table 4. Evaluation results of the relationship between the level of financing public services and the level of tax burden on legal entities

\begin{tabular}{|c|c|c|c|c|c|}
\hline \multirow[b]{2}{*}{$\begin{array}{l}\text { Public expenditure } \\
\text { parameter }\end{array}$} & \multicolumn{2}{|c|}{ Coefficient in the regression equation } & \multirow[b]{2}{*}{$\mathrm{F}_{\text {act. }}$} & \multirow[b]{2}{*}{$F_{\text {crit. }}$} & \multirow[b]{2}{*}{ Prob $>F$} \\
\hline & $\begin{array}{l}\text { With the public expenditure } \\
\text { parameter }\end{array}$ & At the control variable & & & \\
\hline$E E_{G D P}$ & $\begin{array}{l}-1.068 \\
(-0.88)\end{array}$ & $\begin{array}{l}0.203 \\
(1.56)\end{array}$ & 2.28 & 3.14 & 0.1099 \\
\hline$H E_{G D P}$ & $\begin{array}{l}-3.182 \\
(-1.30) \\
\end{array}$ & $\begin{array}{l}0.129 \\
(0.87) \\
\end{array}$ & 2.84 & 3.14 & 0.0654 \\
\hline$S E_{G D P}$ & $\begin{array}{l}-1.011 \\
(-1.39) \\
\end{array}$ & $\begin{array}{l}0.136 \\
(1.01) \\
\end{array}$ & 2.43 & 3.14 & 0.0971 \\
\hline$T C E_{G D P}$ & $\begin{array}{c}-8.584 * * * \\
(-5.61)\end{array}$ & $\begin{array}{l}0.143 \\
(1.38)\end{array}$ & 17.87 & 3.14 & 0.0000 \\
\hline$D E_{G D P}$ & $\begin{array}{l}-0.854 \\
(-0.85) \\
\end{array}$ & $\begin{array}{l}0.216 \\
(1.72) \\
\end{array}$ & 1.79 & 3.14 & 0.1758 \\
\hline$A E_{G D P}$ & $\begin{array}{l}2.860 \\
(0.81)\end{array}$ & $\begin{array}{l}0.248^{*} \\
(1.98)\end{array}$ & 2.19 & 3.14 & 0.1202 \\
\hline$M E_{G D P}$ & $\begin{array}{l}9.247 \\
(0.66) \\
\end{array}$ & $\begin{array}{l}0.104 \\
(1.36) \\
\end{array}$ & 1.25 & 3.14 & 0.2942 \\
\hline$T E_{G D P}$ & $\begin{array}{c}-1.302 * * * \\
(-6.49) \\
\end{array}$ & $\begin{array}{l}-0.170 \\
(-1.47) \\
\end{array}$ & 24.17 & 3.14 & 0.0000 \\
\hline$E E_{p c}$ & $\begin{array}{l}0.003 \\
(0.23) \\
\end{array}$ & $\begin{array}{l}-0.002 \\
(-1.15)\end{array}$ & 0.72 & 3.14 & 0.4897 \\
\hline$H E_{p c}$ & $\begin{array}{l}0.005 \\
(0.44)\end{array}$ & $\begin{array}{l}-0.002 \\
(-1.24)\end{array}$ & 0.79 & 3.14 & 0.4564 \\
\hline$S E_{p c}$ & $\begin{array}{l}0.001 \\
(0.19)\end{array}$ & $\begin{array}{l}-0.001 \\
(-1.19)\end{array}$ & 0.71 & 3.14 & 0.4940 \\
\hline$T C E_{p c}$ & $\begin{array}{l}-0.015 \\
(-0.97) \\
\end{array}$ & $\begin{array}{l}-0.000 \\
(-0.26) \\
\end{array}$ & 1.16 & 3.14 & 0.3214 \\
\hline$D E_{p c}$ & $\begin{array}{l}-0.009 \\
(-0.50)\end{array}$ & $\begin{array}{l}-0.001 \\
(-1.07)\end{array}$ & 0.82 & 3.14 & 0.4439 \\
\hline$T E_{p c}$ & $\begin{array}{l}-0.003 \\
(-1.46)\end{array}$ & $\begin{array}{l}-0.000 \\
(-0.22)\end{array}$ & 1.88 & 3.14 & 0.1607 \\
\hline
\end{tabular}

According to the criteria of adequacy and statistical significance, two models are used for further calculations, which have the following form (equation 2).

$$
\begin{aligned}
& \operatorname{Tax}_{\text {Pr ofit }}=-1.302 T E_{G D P}-0.170 G D P_{g r}+84.598 \\
& \operatorname{Tax}_{\text {Pr ofit }}=-8.584 T C E_{G D P}+0.143 G D P_{g r}+62.267
\end{aligned}
$$

Based on the presented dependencies, the level of tax burden on legal entities that can be considered optimal for the country in conditions of tax competition between the 11 countries studied was calculated. A summary of the results assessing the compliance of tax burden on legal entities with the level of financing public services in Ukraine is presented in Table 5 .

Table 5. Compliance of actual level of tax burden on legal entities to the level, justified the volume of public expenditure for financing public services in Ukraine in 2005-2012

\begin{tabular}{|c|c|c|c|}
\hline \multirow{2}{*}{ Year } & \multirow{2}{*}{ Actual level } & \multicolumn{2}{|c|}{ The estimated level is justified by corresponding parameter of state expenses } \\
\cline { 2 - 4 } & & TEGDP $_{\text {G }}$ & TCEDP \\
\hline 2005 & 57.30 & 50.82 & 55.42 \\
\hline 2006 & 57.10 & 50.55 & 52.73 \\
\hline 2007 & 56.60 & 51.78 & 49.15 \\
\hline 2008 & 57.20 & 51.04 & 53.65 \\
\hline 2009 & 57.20 & 52.56 & 50.14 \\
\hline 2010 & 55.50 & 47.37 & 53.83 \\
\hline 2011 & 57.10 & 46.29 & 49.88 \\
\hline 2012 & 55.40 & 45.99 & 48.32 \\
\hline
\end{tabular}


The ratio of actual level of tax burden on legal entities in Ukraine and its calculated value, confirmed by the level of aggregate state social expenditure in the country's GDP, has shown a significant overstatement of actual level of tax burden on this category of taxpayers in comparison with the amount of public goods financing that domestic residents receive compared with the conditions prevailing in countries - the tax rivals of Ukraine. At the same time, it should be noted that the level of the gap is significantly increasing starting from 2010, which indicates the deterioration of Ukrainian tax competitiveness in the process of competition for the allocation of capital.

At the same time, the results of calculations carried out for main tax competitors of Ukraine show that Bulgaria, Georgia, Latvia, Slovakia, Moldova and Serbia demonstrate the best competitive positions in this indicator, while Lithuania, the Czech Republic and Estonia are characterized by an increased level of tax burden on legal entities. The revealed links between the level of public spending on transport and communication and tax burden on legal entities allowed to calculate its optimal level in the conditions of tax competition, the value of which for Ukraine confirms the overstatement of tax burden on enterprises, especially in 2011-2012. At the same time, among the other countries studied, Bulgaria, Georgia, Romania, Serbia were the best competitors in this parameter and the worst - Latvia, Lithuania, the Czech Republic, Estonia, Slovakia. To assess the dependence between the level of financing public services and the level of taxation of incomes of individuals, 14 models were also constructed, the parameters of which are summarized in Table 6.

Table 6. Assessment results of the relationship between the level of financing public services and the level of tax burden on individuals

\begin{tabular}{|c|c|c|c|c|c|}
\hline \multirow{2}{*}{$\begin{array}{c}\text { Public } \\
\text { expenditure } \\
\text { parameter }\end{array}$} & \multicolumn{2}{|c|}{ Coefficient in the regression equation } & \multirow[b]{2}{*}{$\mathrm{F}_{\text {act. }}$} & \multirow[b]{2}{*}{$\mathrm{F}_{\text {crit. }}$} & \multirow[b]{2}{*}{ Prob $>$ F } \\
\hline & $\begin{array}{l}\text { With the public expenditure } \\
\text { parameter }\end{array}$ & At the control variable & & & \\
\hline$E E_{G D P}$ & $\begin{array}{l}-1.771 \\
(-1.00) \\
\end{array}$ & $\begin{array}{l}-0.061 \\
(-0.31) \\
\end{array}$ & 0.50 & 3.19 & 0.6069 \\
\hline$H E_{G D P}$ & $\begin{array}{c}-8.688^{*} \\
(-1.79)\end{array}$ & $\begin{array}{l}-0.255 \\
(-1.11)\end{array}$ & 1.61 & 3.19 & 0.2096 \\
\hline$S E_{G D P}$ & $\begin{array}{l}0.272 \\
(0.21) \\
\end{array}$ & $\begin{array}{l}0.009 \\
(0.04) \\
\end{array}$ & 0.02 & 3.19 & 0.9784 \\
\hline$T C E_{G D P}$ & $\begin{array}{c}-6.434 * * \\
(-2.07) \\
\end{array}$ & $\begin{array}{l}-0.031 \\
(-0.15) \\
\end{array}$ & 2.15 & 3.19 & 0.1284 \\
\hline$D E_{G D P}$ & $\begin{array}{l}5.538 * * * \\
(3.14)\end{array}$ & $\begin{array}{l}-0.080 \\
(-0.42)\end{array}$ & 4.92 & 3.19 & 0.0115 \\
\hline$A E_{G D P}$ & $\begin{array}{l}-0.586 \\
(-0.10)\end{array}$ & $\begin{array}{l}-0.036 \\
(-0.19)\end{array}$ & 0.02 & 3.19 & 0.9808 \\
\hline$M E_{G D P}$ & $\begin{array}{l}-26.176 \\
(-0.84)\end{array}$ & $\begin{array}{l}-0.059 \\
(-0.28)\end{array}$ & 0.40 & 3.19 & 0.6711 \\
\hline$T E_{G D P}$ & $\begin{array}{l}-0.635 \\
(-1.29)\end{array}$ & $\begin{array}{l}-0.167 \\
(-0.74)\end{array}$ & 0.84 & 3.19 & 0.4394 \\
\hline$E E_{p c}$ & $\begin{array}{l}0.002 \\
(0.08)\end{array}$ & $\begin{array}{l}0.006^{*} \\
(1.75)\end{array}$ & 1.93 & 3.19 & 0.1570 \\
\hline$H E_{p c}$ & $\begin{array}{c}-0.041 * * \\
(-2.12)\end{array}$ & $\begin{array}{c}0.007 * * \\
(2.43)\end{array}$ & 4.34 & 3.19 & 0.0184 \\
\hline$S E_{p c}$ & $\begin{array}{l}0.009 \\
(0.87)\end{array}$ & $\begin{array}{l}0.006^{* *} \\
(2.13)\end{array}$ & 2.33 & 3.19 & 0.1078 \\
\hline$T C E_{p c}$ & $\begin{array}{l}-0.040 \\
(-1.66)\end{array}$ & $\begin{array}{c}0.008^{* *} \\
(2.61)\end{array}$ & 3.57 & 3.19 & 0.0361 \\
\hline$D E_{p c}$ & $\begin{array}{c}0.106 * * * \\
(3.88)\end{array}$ & $\begin{array}{l}0.003 \\
(1.31)\end{array}$ & 3.04 & 3.19 & 0.0923 \\
\hline$T E_{p c}$ & $\begin{array}{l}-0.002 \\
(-0.58)\end{array}$ & $\begin{array}{c}0.006^{* *} \\
(2.12)\end{array}$ & 2.25 & 3.19 & 0.1154 \\
\hline
\end{tabular}

From the constructed models, the following equation 3 proved to be adequate and statistically significant:

$$
\begin{aligned}
& \operatorname{Tax}_{\text {Salary }}=5.538 D E_{G D P}-0.080 G D P_{g r}+23.342 \\
& \operatorname{Tax}_{\text {Salary }}=-0.041 H E_{p c}+0.007 G D P_{p c}+0.574
\end{aligned}
$$


Using the results of modeling, the level of tax burden on individuals in Ukraine was calculated, which corresponds to the real amount of defense spending and public health expenditure per capita (Table 7).

Table 7. Compliance of actual level of tax burden on individuals to the level, justified the volume of public expenditure for financing public services in Ukraine in 2007-2012

\begin{tabular}{|c|c|c|c|}
\hline \multirow{2}{*}{ Year } & \multirow{2}{*}{ Actual level } & \multicolumn{2}{|c|}{ The estimated level is justified by corresponding parameter of state expenses } \\
\cline { 3 - 4 } & & DE $_{\mathrm{GDP}}$ & $\mathrm{HE}_{\mathrm{pc}}$ \\
\hline 2007 & 33.30 & 29.99 & 12.50 \\
\hline 2008 & 33.30 & 30.01 & 13.45 \\
\hline 2009 & 33.30 & 30.39 & 11.48 \\
\hline 2010 & 34.20 & 28.81 & 12.02 \\
\hline 2011 & 39.15 & 28.58 & 12.01 \\
\hline 2012 & 39.15 & 28.75 & 11.92 \\
\hline
\end{tabular}

Obviously, the actual level of tax burden on wages in Ukraine is overstated and does not correspond to the real volume of government defense spending and the deviation of actual and calculated values of the indicator is growing rapidly starting in 2010 what is the result of imbalances in the fiscal and expenditure policies of the state. Next to this, the results obtained for Ukrainian tax competition countries show that Bulgaria, Georgia and Serbia show the greatest reserve of tax competitiveness in this parameter, while in Latvia, Lithuania, Romania, the Czech Republic, Estonia, Slovakia, the underfunding of public expenditure leads to the loss of tax competitive positions.

One of the most important factors in the effectiveness of social and economic functions of the state for individuals is the level of health care in the country. The ratio of actual level of tax burden on individuals and their calculated value, confirmed by public expenditure on health per capita, showed that in Ukraine there is a persistent overstatement of the taxation level of individual incomes compared to the real volume of financing public goods. However, in the context of Ukrainian tax competition countries, similar trends are typical for Bulgaria, Georgia, Romania, the Czech Republic, Serbia, when the results obtained for Slovakia, Latvia, Lithuania, Estonia show a high level of attractiveness for taxpayers - individuals among the countries surveyed of this parameter.

\section{Conclusions}

The authors for the first time formalized the relationship between the level of tax burden and the level of financing public services based on multifactor dependencies using the panel regression method with fixed effects for Ukraine and its main tax competition countries, which allowed determining the level of tax burden optimal for Ukraine (aggregate physical and legal entities).

Considering the obtained results, it can be noted that the aggregate level of tax burden in Ukraine is close to optimal in the context of tax competition.

In one of the periods studied, the actual level of tax burden on legal entities does not correspond to the value confirmed by real state social expenditure, which leads to a deterioration of Ukrainian competitive positions in the European tax area and the need to increase them for reducing the level of tax burden or increasing the efficiency of socio-economic functions of the country.

It should be noted that the actual level of tax burden on individuals does not correspond to its optimal value in the context of tax competition, the justified volume of state public expenditure.

The obtained results testify to the need to develop a comprehensive concept of economic reforms, which provides for an increase in the efficiency of state expenditure and fiscal policies, taking into account the specifics of their interaction and the redistribution of tax burden between various categories of taxes, with its shift to types of taxes that are not considered by the payers as priorities in making decisions on placement of the objects of taxation, which will increase the competitiveness of tax system.

\section{References}

1. Baldwin, R., Forslid, R. (2002). Tax competition and the nature of capital. London, Centre for Economic Policy Research, 9 p.

2. Batina, R., Ihori, T. (2005). Public Goods: Theories and Evidence. Springer, 420 p. 
3. Collecting Taxes [Electronic source] / USAID Database. - Access mode: https://egateg.usaid.gov/collecting-taxes/.

4. Delgado, F. J. (2013). Are Taxes Converging in Europe? Trends and Some Insights into the Effects of Economic Crisis. Journal of Global Economics, 1(1), 24-26.

5. Feld, L. (2005). Tax Competition: How Great is the Challenge? EKONOMSKI PREGLED, 56(9), 723-758. 6. Ferreira, S., Varsano, R., Afonso, J. (2005). Inter-Jurisdictional Fiscal Competition: a Review of the Litterature and Policy Recommendations. Political Economy, 25(3), 295-313.

7. Field, T. (2003). Tax Competition in Europe and America. State Tax Notes, 98(14), 1211-1216.

8. Gilardi, F., Wasserfallen, F. (2012). How socialization attenuates tax competition [Electronic source]. Access mode: http://www.researchgate.net/publication/228431133_How_socialization_attenuates_tax_competition.

9. Goodspeed, T. (1998). Tax Competition, Benefit Taxes and Fiscal Federalism. National Tax Journal, 51(3), 579-586.

10. Gordon, R., Wilson, G. (2002). Expenditure Competition [Electronic source]. - Access mode: http://www.econ.ucsd.edu/ rogordon/zoning6.pdf.

11. Griffith, R. Klemm, A. (2004). What Has Been the Tax Competition Experience of The Last 20 Years? Institute for Fiscal Studies and University College London Working Paper, No. 5, 33 p.

12. Kleiner, N. (2006). Is Systems Competition a Viable Alternative to EU Tax Harmonisation? Master Thesis, Haifa University, $54 \mathrm{p}$.

13. KPMG Annual Survey of Tax Competitiveness 2014 [Electronic source] / KPMG official web-site in United Kingdom. - Access mode: http://www.kpmg.com/UK/en/services/Tax/Pages/default.aspx.

14. Libman, A. M. (2007). Distribution of Tax Revenues and Tax Authorities in Conditions of Tax Competition. Taxes and Taxation, 6, 23-34.

15. Mitchell, D., Fellow, S. (2013). OECD Launches New Effort to Undermine Tax Competition. Cato Institute Tax \& Budget Bulletin, 68, 12-13.

16. Oates, W., Schwab, R. (1998). Economic Competition Among Jurisdictions: Efficiency Enhancing or Distortion Inducing? Journal of Public Economics, 35, 333-354.

17. Pinto, C. (2002). Tax Competition and EU Law. The Hague-London-New York: Kluwer Law International, $435 \mathrm{p}$.

18. Razin, A., Sadka, E. (1989). International Tax Competition and Gains from Tax Harmonization. National Bureau of Economic Research Working Paper, 3152, $25 \mathrm{p}$

19. Rohac, D. (2006). Evidence and Myths about Tax Competition. New Perspectives on Political Economy, 2(2), 86-115.

20. Statistics of Public Expenditure for Economic Development [Electronic source] / International Food Policy Research Institute. - Access mode : http://www.ifpri.org/publication/public-expenditure-database.

21. Taxation trends in the European Union [Electronic source] / European Commission, 2014. - Access mode: $\mathrm{http} / /$ ec.europa.eu/taxation customs/taxation/gen info/economic analysis/tax structures/index en.htm.

22. Teather, R. (2005). The Benefits of Tax Competition. The Institute of Economic Affairs, $167 \mathrm{p}$.

23. The World Bank : official web-page [Electronic resource] - Access mode: http://data.worldbank.org/indicator.

24. Tiebout, C. (1956). A Pure Theory of Local Expenditure. Journal of Political Economy, 64(5), 416-424.

25. Vasylieva, T., Sysoyeva, L., Samusevych, I. (2014). Tax integration in European countries: development and consequences. European Science Review, 11-12, 103-105.

26. Wildasin, D. (1988). Nash Equilibria in Models of Fiscal Competition. Journal of Public Economics, 35(2), 229-240.

27. Wilson, J. (1991). Tax Competition with Interregional Differences in Factor Endowments. Regional Science and Urban Economics, 21, 423-451.

28. Zodrow, G., Mieszkowski, P. (1986). Property taxation and the underprovision of local public goods. Journal of Urban Economic, 19, 356-370. 


\section{Appendix}

Table 3. Conformity of actual level of the aggregate tax burden to the level, justified the volume of public expenditure for financing public services in Ukraine in 1999-2012

\begin{tabular}{|c|c|c|c|c|c|c|c|c|c|c|c|}
\hline \multirow{2}{*}{ Year } & \multirow{2}{*}{$\begin{array}{c}\text { Actual } \\
\text { level }\end{array}$} & \multicolumn{10}{|c|}{ The estimated level is justified by the corresponding parameter of state expenses } \\
\hline & & $\mathrm{HE}_{\mathrm{GDP}}$ & $\mathrm{EE}_{\mathrm{GDP}}$ & $\mathrm{TE}_{\mathrm{GDP}}$ & $\mathrm{SE}_{\mathrm{GDP}}$ & $\mathrm{TCE}_{\mathrm{GDP}}$ & $\mathrm{DE}_{\mathrm{GDP}}$ & $\mathrm{AE}_{\mathrm{GDP}}$ & $\mathrm{ME}_{\mathrm{GDP}}$ & $\mathrm{DE}_{\mathrm{pc}}$ & $\mathrm{TE}_{\mathrm{pc}}$ \\
\hline 1999 & 12.99 & 13.04 & 14.42 & 9.09 & 13.61 & 12.66 & 15.06 & 14.69 & 13.86 & 14.28 & 14.75 \\
\hline 2000 & 14.10 & 13.30 & 15.34 & 11.99 & 15.95 & 13.03 & 15.30 & 14.27 & 14.57 & 14.52 & 14.93 \\
\hline 2001 & 12.06 & 13.83 & 16.10 & 11.99 & 13.96 & 12.95 & 15.58 & 14.70 & 15.02 & 14.85 & 14.91 \\
\hline 2002 & 13.10 & 14.44 & 16.83 & 11.32 & 12.61 & 13.23 & 14.97 & 14.92 & 15.69 & 14.46 & 14.93 \\
\hline 2003 & 13.65 & 15.69 & 17.21 & 12.55 & 12.67 & 13.73 & 14.94 & 15.87 & 15.80 & 14.58 & 15.03 \\
\hline 2004 & 13.28 & 15.52 & 16.98 & 14.01 & 14.15 & 15.26 & 15.18 & 15.57 & 15.93 & 14.98 & 15.21 \\
\hline 2005 & 17.12 & 14.86 & 17.47 & 13.63 & 18.26 & 13.80 & 14.67 & 15.37 & 15.78 & 14.47 & 15.38 \\
\hline 2006 & 17.75 & 15.27 & 17.85 & 14.21 & 16.89 & 14.57 & 14.40 & 15.64 & 15.82 & 14.32 & 15.42 \\
\hline 2007 & 16.48 & 15.39 & 17.81 & 13.84 & 15.00 & 15.33 & 14.92 & 15.66 & 15.67 & 14.99 & 15.42 \\
\hline 2008 & 17.86 & 14.87 & 17.90 & 13.51 & 15.84 & 14.14 & 14.83 & 15.71 & 15.82 & 14.88 & 15.54 \\
\hline 2009 & 16.37 & 14.77 & 18.22 & 11.17 & 14.39 & 14.05 & 14.66 & 14.69 & 15.37 & 14.35 & 15.47 \\
\hline 2010 & 15.52 & 16.12 & 18.91 & 15.01 & 17.40 & 14.20 & 14.48 & 14.99 & 15.90 & 14.37 & 15.61 \\
\hline 2011 & 18.50 & 15.54 & 17.69 & 15.51 & 17.20 & 15.05 & 14.42 & 15.65 & 16.04 & 14.71 & 15.81 \\
\hline 2012 & 18.20 & 15.35 & 18.09 & 15.09 & 16.98 & 15.14 & 14.39 & 15.63 & 15.78 & 14.76 & 15.93 \\
\hline
\end{tabular}

Note: this table shows the maximum and minimum levels of aggregate tax burden, confirmed by government spending on financing public services. 